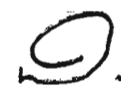

\title{
$869.9-5$
}

\section{Oração de paraninfo aos bacharéis de 1960.}

\author{
Luís Eulalio de Bueno Vidigal \\ Catedrático de Direito Judiciário Civil na \\ Faculdade de Direito da Universidade de
}

Volto, depois de longo tempo - o tempo que separa a minha da vossa geração - a ocupar a tribuna de que uma vez me acerquei, trêmulo, emocionado e cheio de esperança. A mesma festa, a mesma escola e o mesmo orador. E, no entanto, quanta cousa mudada nestes trinta anos! No local em que hoje está a escola ontem se erguia velho convento franciscano de dois pavimentos. $O$ candidato ao vestibular atravessava o velho largo da cidade que, com suas pequenas casas térreas, ainda não tinha pretensões a metrópole e caía de chôfre, sob a zombaria dos veteranos, em pleno periodo colonial. Os que vinham de escolas modernas - e eram quase todos - assombravam-se de encontrar alí salas e salões que eram verdadeiros corredores. De um dêles se podia assistir à missa da Igreja de São Francisco. No salão nobre, comprido e estreito, ostentando aquêle mesmo Pedro II que ainda hoje lá vêdes, além do doutoral quase nada se ouvia. O mobiliário rescendia ao fim do século. Foi Alcântara Machado, paraninfo nesse dia, e diretor da escola, quem, sob o protesto de muitos, corajosamente mandou demolir o casarão e reerguê-lo com o aspecto que hoje tem. Conservou da velha casa os dois páteos: o grande, das arcadas, que faz a gente sentir-se na escola de hoje como se estivesse na de outrora; o pequeno, que abriga uma sepultura em que alguns perpetuam o culto à memória de um velho mestre do curso anexo; outros vêem o símbolo de uma era de rea- 
ção oligárquica que a nova república veio destruir; e em que ninguém, capaz de sonhar, pode deixar de ver uma das mais saborosas legendas da tradição acadêmỉca.

A festa é a mesma: os pais, os irmãos, as noivas do grande número; as mulheres e os filhos de alguns; e, como sempre, entre aquêles que tudo esperam do futuro, alguns já vitoriosos, que se não desdouram de acrescentar a seus triunfos da mocidade e da idade madura o título de bacharel que outros tanto malsinam.

A escola seria a mesma? Que era a Faculdade de Direito de São Paulo há trinta anos? Era, e não podia deixar de ser, o que dela haviam feito seus cem anos de existência. Juntamente com a gloriosa irmã do Recifé, estivera, por mais de um século, a ensinar a ciência jurídica, e, com as demais escolas jurídicas do Brasil, detinha, até então, o privilégio de ensinar tôdas as ciências sociais. Afluíam, portanto, para as escolas de direito os poetas, os políticos, os sociólogos, os filósos, os críticos, os jornalistas, os oradores. Sendo assim, como admirar-se de que, entre as figuras ilustres de nosso passado, venerássemos a CASTRO Alves mais do que a João Mendes Júnior; a Álvares de Azevedo mais do que a Pedro Lessa; a Ruy e Nabuco, mais do que a Crispiniano e Ramalho?

Em 1930 devia, pois, a Faculdade ser escola de direito, de política, de letras, de filosofia, de sociologia. De então para cá diversificou-se o ensino. Criou Alcântara MachaDo a Escola de Sociologia e Política, instituto particular logo seguido pela Universidade de São Paulo, que acrescentou às antigas escolas a Faculdade de Ciências Econômicas e Comerciais e a Faculdade de Filosofia, Ciências e Letras, com as secções de Geografia e História, Ciências Sociais e Políticas, Letras Clássicas, Línguas estrangeiras, Filosofia. À medida em que essas escolas se foram projetando, foi a Faculdade de Direito se tornando, cada vez mais, escola para juristas. Se confrontardes o corpo docente de hoje com o de 1930, vereis como prevalecem agora 
os cientistas do direito e vão, aos poucos, desaparecendo os políticos.

O orador de hoje é o mesmo de ontem? É, sem dúvida. Separa-os, porém, uma geração. Aquêle que então falou em primeiro lugar, se maravilha de hoje falar por último. Orador e paraninfo, outrora, segundo o espírito da escola, preocupavam-se, acima de tudo, com a política do Brasil e de São Paulo. Um e outro, esquecidos de que falavam principalmente a futuros advogados, juízes, promotores, delegados, só cuidavam da salvação do Brasil, pela redenção de São Paulo, na pregação que empolgava a todos e de que, em breve, eclodiria a revolução paulista.

Acreditávamos, nessa hora, no futuro, e certamente perderíamos o ânimo se nos dissessem que passariam uma revolução, vários levantes, uma guerra e cinco golpes de estado, antes que víssemos o Brasil em pleno regime de representação popular e São Paulo definitivamente - esperemos - entregue a seus filhos.

Bacharéis em direito, que hoje vos tornais, haveis de indagar: tem o jurista lugar de preeminência na sociedade contemporânea? Muitos de nossos mestres de gerações passadas, e alguns contemporâneos, timbram, na esteira do Cardẻal De Luca, em atribuir-lhe êsse pôsto. "Em que pese, aos que, tocados de inveja, rivalidade ou inconciência, murmuram contra o que pejorativamente denominam a casta dos bacharéis" - disse Francisco Morato - "certo é que aquêles que com preparo, vocação e treino, se dedicam ao mister de defender o organismo jurídico social, adquirem uma pericia e superioridade que refogem ao comum dos homens, na elaboração e inteligência das leis, no tráfico da vida civil, no entravamento e meneio dos negócios públicos. Não há vituperá-los de se arrogarem vaidosamente preeminência entre os que exercitam na vasta e luminosa esfera da intelectualidade".

Miguel Reale, vosso mestre de ontem, é mais incisivo ainda: "Apaguem-se da história do Brasil as obras de nossos bacharéis, e que restará da vida cultural e política 
do Império e da República? Que restará de nossas letras, de nosso romance, de nossa oratória, de nosso jornalismo, de nossa historiografia, de nossa poesia? Que restará do pensamento filosófico sem os bacharéis TobIas Barreto, Farias Brito, Pedro Lessa, João Mendes Júnior, Clóvis BeVILAQUA?"

Pois bem, meus jovens colegas. Por mais que me desvaneçam as palavras dêsses mestres queridos, pesa-me dizer-vos que, a meu ver, não mais tem o bacharel o primado que outrora com inveja e injustiça lhe contestavam. Tanto mais me pesa proclamá-lo quando me lembro da candente crítica de Erasmo: "entre os eruditos, os juriconsultos se atribuem a primazia, e ninguém existe que tanto se compraza consigo mesmo". Disse-vos, há pouco, que as escolas de direito, e a nossa particularmente, vinham perdendo seu caráter de universidadès de ciências sociais, e se iam tornando, paulatinamente, verdadeiras escolas de ciência e técnica jurídicas. Nessa transformação encontrareis, talvez, a explicação para o desaparecimento do primado dos bacharéis. O culto da ciência não outorga prestígio social. Quereis, através de um exemplo augusto, a comprovação? Se há um povo e uma época, que dispensaram consideração excepcional à classe dos juriconsultos, êsse povo é certamente o romano do período clássico. Salientou recentemente Biondo Biondi, em magnífico ensaio que intitulou Existencialismo jurídico $e$ jurisprudência romana, que o mérito dos juristas romanos não está em haver fixado os "praecepta juris" ou as categorias jurídicas fundamentais, mas, principalmente, na fina percepção do justo e no ter excogitado meios adequados para atingí-lo. Isso explica - acrescenta - porque eram tidos na mais alta conta pela opinião pública, e colocados a altitude a que nenhum jurista moderno, com tôdas as suas doutrinas e os seus sistemas, poderia, nem de longe, aspirar. Quereis saber o que valiam como juristas êsses príncipes da sociedade romana? Não me abalançaria a dizê-lo se, para tanto, não me bastasse repetir, daquele ilustre romanista, 
a crítica impiedosa, mas de procedência irrecusável: "Escreviam trabalhos e monografias tão modestos do ponto de vista contemporâneo que, se se apresentassem a concurso para uma cátedra universitária, seriam solenemente rejeitados por falta de método jurídico. Para chegarem às soluções que reputavam justas, não hesitavam em fantasiar etimologias, forjar origens históricas imaginárias, e até invocar versos de HoMero para dirimir controvérsias jurídicas".

Os juristas modernos sabem que o direito não é sòmente "ars boni et aequi", como pretendeu Celso. Mas pagam, na consideração pública que perderam, pelo terreno que a técnica conquistou à justiça. Se o jurista não é mais o sacerdote do bom e do justo, será, porventura, cientista do direito? Filósofo? Técnico? Artista? A ciência do direito tem dois setôres de pesquisas: um setor de realidade jurídico-natural anterior ao direito constituído e um setor de realidade jurídico-positiva consistente no direito constituído. Entre os dois setôres está uma fase técnica, a legislação. Quando o jurista dirige sua pesquisa para o fato ainda não regulado pelo direito, faz obra de cientísta. é cientista também quando trabalha sôbre os postulados do direito positivo. A ciência é indiferente, melhor diriamos cega, para os valores. Se o jurista indaga, não a respeito do que "é", mas a respeito do que "deve ser", trabalha como filósofo. É por não terem compreendido, ou talvez por propositadamente não aceitarem, essa distinção entre ciência e filosofia, que certos doutrinadores de estados modernos, de propaganda dirigida, pretendem ser o direito fenômeno burguês destinado a desaparecer no estado socialista.

A técnica da legislação consiste em assenhorear-se das verdades reveladas pela ciência e dos valores apontados pela filosofia e empregá-los para fins práticos. Vãs têm sido tôdas as tentativas de assegurar, nesse campo, senão a exclusividade, pelo menos a decidida participação dos juristas. Há muitos séculos, da codificação de Justiniano 
aos códigos contemporâneos, vemos invariàvelmente participlar o jurista da elaboração dos grandes monumentos legislativos. Provêm, entre nós, da pena de juristas, o Código Civil, a Lei de Falências, a Lei Cambial, o Código Penal, os códigos de processo civil e penal, e tantos outros: Mas, ao lado dêsses salutares exemplos, quantas leis importantes feitas à revelia dos juristas! Quantas leis fiscais, administrativas, trabalhistas, e até constitucionais, elaboradas por leigos. $E$ não fôra a coincidência de fazerem parte dos corpos legislativos do Estado e da República alguns bacharéis, estou em que êstes teriam sido definitivamente banidos das comissões redatoras de nossas leis. Ainda, porém, quando nelas não colabora diretamente, exerce o jurista sua técnica emitindo e apurando os conceitos, determinando os comportamentos individuais, distinguindo-os uns dos outros, reagrupando-os, classificando-os, reunindo-os em sistema.

O homem que faz a lei (mas não necessàriamente o jurista) é também, de certa forma, artista. Disse-o um dos maiores ensaistas jurídicos do nosso tempo, embora antes tenha afirmado que o direito, o mais rígido dos produtos culturais, e a arte, a mais sutil das formas de expressão do espírito, vivem sempre nas piores relações possíveis. Os artistas desprezam o direito e têm aversão às coisas do fôro. No entanto, è requisito elementar, embora não especifico do jurista, ser capaz de exprimir-se, oralmente e por escrito, com perfeição. Não se exigem, para a linguagem do jurista, tanto como para a do escritor, a nobreza, a correção, a precisão, o decôro, a clareza, a harmonia?

Tudo isso há de ser o jurista nos dias que correm.

Defendei, portanto, vossas prerrogativas de especialistas do direito contra a visão superficial e simplista do homem do mundo. Lembrai-vos do nosso JHering: "Porquê não seria o direito como tôdas as outras esferas do saber humano, onde é exato dizer que a contemplação contínua de um objeto, sua observação e seu estudo constan- 
temente prosseguidos conduzem necessàriamente a conclusões novas que são incompreensiveis, absurdas mesmo, quando objeto de observação superficial? Perante tais variações, um homem do mundo instruído não ousaria, em nenhuma das outras ciências, pretender estar sòzinho com a verdade e acusar a ciência de mentira! E, no entanto, é o que acontece todos os dias quando se trata do direito! Aqui a experiência e o saber são qualificados de êrro e de prevenção, a ignorância absoluta é brindada com o nome de isenção de preconceitos".

Acautelai-vos, pois, contra a apreciação natural, contra as concepções primárias do bom senso do homem comum. Mas guardai-vos, também, da jactância que, tantas vêzes, subtrai a nossa classe as simpatias de que, por tantos titulos, é merecedora.

E costume antigo, muitas vêzes seguido e outras tantas evitado, o de desdobrar o paraninfo a seus alunos os vários campos possíveis de sua atividade futura, aconselhando-os e orientando-os em cada um dêles. Hesitei muito antes de me resolver a seguir êsse costume. Tantas vêzes já vistes, nas solenidades precedentes, o mesmo quadro, que receei prevalecer-me da tribuna a que me alçou a generosidade de vosso coração de moços, para lhes dar conselhos e opiniões a cada ano repetidos. Tranqüilizai-vos. Muito pouco hei de vos dizer sôbre apenas duas das profissões reservadas aos juristas: a dos advogados e a dos magistrados. Direi de cada uma delas, sem qualquer pretensão de originalidade, apenas aquilo que, embora de todos conhecido, é freqüentemente por muitos esquecido.

Da advocacia, lembrar-vos-ei de que não é profissão para enriquecer a quem quer que seja. Antes de que possais com ela contar para vossa subsistência, hão de passar, para a grande maioria, muitos anos. Concito-vos, não obstante, a exercê-la com desprendimento e abnegação. É preferível buscar em outras atividades o necessário para viver, que a advocacia sòzinha não dá, do que mercantilizá-la ou desvirtuá-la pela subserviência a que são compe- 
lidos tantos pobres advogados para satisfação de maus clientes. $\mathrm{E}$ indicarei, como as maiores qualidades do advogado, sem falar na probidade (que é elementar), antes do próprio amor ao estudo e ao trabalho, antes da urbanidade para com juízes e colegas, a combatividade e - apesar das decepções que a fortuna vos irá deparando a cada passo a confiança na justiça.

Se fordes magistrados, não vos deixeis dominar pea tentação de fazer justiça a qualquer preço, sem a lei ou contra a lei. Bem sabeis que o juiz é escravo da lei. Quando queremos elogiar um juiz, lembra RADBRucH, nunca o chamamos legalista, mas apenas justo, porque um juiz que cumpre a lei é já por isso mesmo, e só por isso, um juiz justo. Desconfiai sempre dos chamados juịzes humanos, permanentemente propensos a julgar por eqüidade, a quem não têm faltado os louvores de falsos juristas. A lei, e não o juiz, é a suprema garantia dos direitos e liber= dades individuais. Se fordes inflexíveis aplicadores da lei, ser-vos-á fácil pairar, com objetividade, acima das lutas e controvérsias dos litigantes, porque nunca, como juizes, deveis perder a serenidade. 0 calor e a paixão não são o ambiente propício para a busca da verdade e da justiça. Para os advogados, que se defrontam nos prélios judiciários, são qualidades, porque os excessos de um e outro se compensam. Mas o juiz, que interpreta soberanamente a lei e, dentro de seus limites, dispõe de fôrça quase incontrastável, nunca deve descer ao campo raso dos postulantes e seus patronos.

Como vêdes, do muito que vos poderia dizer, disse pouco dos juristas em geral, menos ainda dos advogados e juizes. Esqueci de propósito os políticos. Renunciemos, na complexa sociedade de nossos dias, a pleitear as altas posições do parlamento e da administração, que foram, por um século, o privilégio dos filhos das academias de São Paulo e do Recife. Contentêmo-nos com os louros de nosso passado, que já demos oito presidentes da República ao país. Voltêmo-nos agora, fiéis ao novo espírito que impera 
em nossa alma-mater, para a ciência e para o estudo, a fim de que possamos dêsse campo, que é exclusivamente nosso e que ninguém nos disputa, conquistar, e derramar sôbre São Paulo e o Brasil, as mesmas glórias com que, na política e nas letras, os filhos da Faculdade de Direito vêm, há mais de um século, mostrando-se dignos da educação e dos ensinamentos que alí receberam. 